\title{
Adult Education, narratives and cultural values
}

\begin{abstract}
In these recent decades, mainly in the western world, we have experienced and are still experiencing profound economic and social changes, which give way to new and different migratory fluxes in the search for better living conditions. In this manner the human tissue that composes societies is today certainly diverse. There we can now find new minorities originating from immigration, whose members possess ethnic, religious, cultural and linguistic characteristics differing from those of the rest of the population of the host communities, which often bring about problems of intolerance, injustice and radicalism. Education, especially adult education, can play a special role in the eradication of those phenomena through the analysis of some contents of narratives or short stories. These contents encourage the dialogue and the interaction, aid the integration, stimulate mutual knowledge, promoting peace.
\end{abstract}

Keywords — adult education, dialogue, multiculturalism, narratives, shared cultural values.

\section{INTRODUCTION}

$\mathrm{T}$ he education of adults is often seen in a modernist and postmodernist perspective. However, deep political and economic changes in a globalised world lead us, at present, to face this issue differently: there is a demand for different knowledge and this means constant adaptation even within the posmodernist perspective.

Who is the current adult student, the focal point of learning today?

In a global and multicultural world as the one we live in, we can be talking about someone in the staff of a public or private corporation, recruited abroad; or the young foreigner looking for a job and trying to settle down in the host country; but it most probably is the immigrant, man or woman, looking for better living conditions.

These adult students are not only the product of the technical learning they may have acquired, they also portray the (political, economical, social and religious) contexts in which they were born and grew up. From this derives the need that adult students have to understand those with whom they are going to share their workplace, as well as the need to be understood by them.

So, notwithstanding the fact of that people are highly influenced by external incentives (as in the case of a job promotion), the internal factors (as the understanding of cultural differences, or the building up of self-esteem) are the ones which most encourage and motivate their search for knowledge and the need for new learning experiences.

So, for the educators it is essential to know who they are addressing, who these adult students are, acknowledging the cultural differences, learning about their life experience and beliefs; that is today a basic condition.

Paulo Freire [1], [2], whose thoughts and performance were guided by a dialogical practice, advises educators to practice dialogue and interaction with the students. Brookfield [3] also refers that there are in the life of individuals subtle relations of power, leading to deflecting ways of thinking and being. And 
he insists on the need to deconstruct ideas and actions taken as resulting from wisdom and common sense, uncritically accepted. The educator's job is to guide students to think and act differently. Furthermore, listening and talking with other people will give way to a more conscious perception of how individuals acknowledge their ideas and actions.

In short, we could say that the motivation to learn is also connected to the understanding that others have of us, and to the knowledge we have about the others.

\section{NARRATIVES IN THE PROMOTION OF THE HUMAN BEING'S KNOWLEDGE}

In oral tradition, since ancient times, short stories have been used to convey and encourage human knowledge. To prove this are the great Greek and Latin narratives, which continue to be studied, and so are the Judaic, Christian, Islamite, Buddhist and Hindu, whose influence on individuals' education have built such differentiated civilizations. Historically more recent, fables, for instance, also depict individual or social models of behaviour, leading individuals to reflect upon more conscious options of life.

Furthermore, in occidental civilization and with the advent of literacy, narratives have been the motivation and have acted as means of conveying other kinds of knowledge: they disseminate information which can be either geographic, ethnic, anthropologic, or on natural phenomena.

From the point of view of the formal education of adults, and as referred by Nóvoa [4] and Magalhães [5], narratives and their value have been recognized to be important and useful means of learning. Our experience of several years with adult students also reveals they show great interest for the study of these texts. José Alves and Óscar Gonçalves say that human knowledge is often expressed through stories. When someone is not able to state the sense or meaning of an event, idea or concept through a logical and propositional reasoning, they resort to analogy, by telling a story. It is as if, these authors state, one "could not reach the explicit without going first through the implied" [6]. If we remember the explanations we give to our students in classroom so that they can better understand the subjects, or the analogies that the scientist uses to make himself understood by the layman, we often realize that narratives are 'the required mediators' that enable us to achieve the human knowledge in a better and adjusted way. Furthermore, and as referred above, economical social and intellectual conditions of life today are mixed up with matters such as multiculturalism, diversity, and heterogeneity. Stories are trans-cultural, they are composed by elements scarcely belonging to a place or social group and these elements are the ones that attribute meaning to what we want to be and the way we want to follow.

Making them a stimulating agent of knowledge of the self and of the others, is then, as stated by Silva [7], essentially related to the following:

1) narratives are considerations about human beings, representing their way of thinking and acting, i.e., they are representations of reality whose approach, or approaches may be adapted to different listeners with different levels of knowledge;

2) they are created in recognizable spaces and times - either internal or external - representing a 'continuum' of actions, thoughts, or patterns of behaviour, that together lead the events; 
Adult Education, narratives and cultural values

3) through narratives one can gain the mental distance towards one's own story of life and assess its coherence with the multiple "selves" in it;

4) they present steady and substantive descriptions of human lives.

\subsection{Stories as Pre-text to the Practice of Dialogue}

There are certainly many and different types of narratives - musical, pictorial, museological or others - but it is written narratives that we are going to address here. And we selected the contents of some short stories by Mia Couto, seeing that he is able to add another characteristic to the ones referred above: he moulds simple subject matters to deep meanings. As a camera changing leisurely its angles of focus, so his stories put on view different perspectives according to our outlook upon life, claiming for profound considerations, critical analysis and new assessments for which we are not often prepared.

Mia Couto was born in Mozambique where in his first years he lived the colonization experience and, at a later period, the civil-war and the post-war time, where new forms of colonization also settled down. The sight of these three periods gives voice to his stories. They are pre-texts inspired in the acknowledgment, for example, of the universality of human rights, that serve as pretext to reflect upon human action. Across them we can find different ways of human interaction, revealing what we really are and what we would like to become.

In stories like O Embondeiro que Sonhava Pássaros [8], A Mancha [9], A Praça dos Deuses [10] e Balões dos Meninos Velhos [11], among others, Mia Couto raises vital issues that give way to discussion and debate. His suggestive language and simplicity render the dialogue with ourselves and the contexts we live in, easy.

In the universe of the $O$ Embondeiro que sonhava pássaros, the period of colonialism serves only as background to a scenery where inequity in political, economic, social and cultural interaction stands out.

When the hawker barefooted and deeply bent by the pressure of the cages of birds, crosses the residential quarter of the white people, the narrator tells: "watching behind curtains, the colonists reprove such abuse. And they teach their children - Who is that black man? Who knows him? His barefoot may even befoul the place! No, no and no. The black man must go back to his place". [8] The contrast comes out, showing two perspectives: that of the colonist and that of the native. The first arbitrarily discriminates the second. The colour of his skin, the different way of life, the scarcity and the poverty of his clothes are pretexts to exclude him. The claim and interest to keep away "the barefoot black man (...) the tramp, who arrogate himself to exist, disregarding the duties of his race" [9], plainly show the prerogatives some men think to have over others. This claim is an unquestionable assertion. They do not even place the possibility of having, really, permuted their roles with the natives, because, in fact, the advantages the settlers assume to have were attained by force, and so, illicit. Nevertheless the sense of superiority they consider to have is obvious. The passage about the black man walking through the residential quarter of the white is regarded as an 'intolerable abuse' that the young generation has to learn to prevent. The rationality of the individual is devalued and, in the process of teaching and transmitting values, the paternal point of view prevails. Intolerance becomes dislike and authoritarianism, disguised as authority, becomes indoctrination. This 
exaggerated aggressiveness is then justified by the supreme value the white man attributes to himself and his condition of settler, to such an extent that he denies the value of all other men. Racism and intolerance are nourished in the belief that the colonized societies only bring forth primitive civilizations and that the local natives, witnesses of the wisdom of the settlers, only improve by the proximity of the 'developed' invader who explored, with his technique and technology, their raw-materials which did not belong to him but he exported and used as support to his own development and affluence. Nevertheless, this logic of power is obviously differently conceived by the settler. In our hawker, however, what seems to be acculturation is simply imitation. Though wearing a suit and a tie to welcome the white men, he keeps culturally different, "being more a legend than reality" [10] The injustice he is subjected to does not lead him, however, neither to a desire of revenge nor a feeling of underestimation. In fact his tolerance is not part of the awareness of his lack of freedom and power, but is built and made firm upon an attitude of ideal relationship with others.

It is also possible to view the life of colonists in another perspective. Their domination is opposite to freedom. The colonists are obstacles to the way of living of natives as they have no right to live their lives as they wish. They lack, first and foremost, an objective dimension of freedom, without which it is in fact inexistent.

The scenery of the story $A$ Mancha reveals the result of a huge and long civil war. Living in a place "where bullets seemed to be rain" [11] Caroline did survive inland. Her sons and grandsons, as they did not live the war as she did, have a distorted dimension of freedom. In the capital, away from the chaos of wrangling and weapons, attacks and fear, laying on a comfortable sofa, sons and grandsons watch television where the news identify a fratricidal war with the struggle for freedom. This distortion can also be seen in other moments of the plot: the bewilderment of Carolina in the sight of such sumptuousness, such fullness of 'carpets, marbles, cars and whiskies' quiets down when she finds a logical explanation for such things, "was not the war for the well-being of the people?" [12]. Soon the perplexity gives place to doubt. Seated in front of the television set or watching a video, sons and grand-sons do not talk. Television is now the main promoter of family interaction, the priority, competing with the will of Carolina to tell stories, "warming all hearts" [13]. Children's headphones, the folly of her sonin-law with sun glasses inside the house and the worry of Carolina's daughter to look physically well are signals that each one is only turned into himself. The accumulation of assets - "replete bags, and the house stuffed with luxury" [14] gives the idea of prosperity and happiness and the gift to Carolina of "nice clothes, high-heeled shoes and sun glasses" [15] confirm her family's hopes of contributing to fulfil that task. Alienated, they lack the ability to decide by themselves about their wishes and solidarity.

When Caroline finds herself in the street for the first time and "sees the children going about in rags, asking for charity" [16], she becomes aware that "the treasures of this life are not equally shared." [17]. Solidarity, as opposed to indifference, is here the essential idea. Carolina's sons and grandsons are not worried about others. Placing their well-being in the core of their attention, they deny fair and equitable reciprocity. With no resources, the masses are out of the system and those who live better disregard poverty. Being economically indifferent, they are morally indifferent too. So, the unconcern before indigence and weakness of others opposes to solidarity. The speech about solidarity 
delivered by Carolina's sons - compared with her engagement and abnegation in her small village on behalf of other people - is now reduced to some despotic agreements and forced social rules. Solidarity that should warrant cohesion, national unity and new principles for this new society, grew too weak and was overtaken by mercantile concerns that impose the supremacy of these rules to others.

The context of the story Balões dos Meninos Velhos also shows a pattern of solidarity that though being consistent with helping others, is supported by an instrumental basis. The problem of exclusion is the main topic to understand the omission of solidarity towards the elderly in contemporary societies. People with no home or comfort, dying slowly "so slowly that one does not notice" [18], share their memories and loneliness.

The shelter and the home as a public place of solidarity limit their action to charity; and the beneficent international organizations seeking name and reputation, "often appear in daily-papers"[19]. Both examples stress the incoherence. What seems to prevail is the image of the man that says to be solidary with seniors but whose goal is to take advantage of the solitary man.

The allegedly moral action, justified only by its material content is, in fact, immoral as the aims of those performing it are displayed.

In the story A Praça dos Deuses, solidarity mingles with philanthropy. Having had a healthy and wealthy life and feeling its end approaching, the muslin Mohamed Pangi wishes to express his gratitude to the gods, as well as "the kindness of the world and its beauties" [20], renouncing to all properties and belongings. In the local square of the island where he lives he gathers all the inhabitants, so that for thirty days they could forget hunger and hardship.

Solidarity means mutual aid, an aid that does not represent either grief or a charitable act. Solidarity demands worry towards others, but only as long as they are free and equal. It is not possible to think of a self without placing, simultaneously, the existence of another that possibly does not speak the same language, and does not have the same beliefs or religion system. A modern and plural society can only be interpreted by the light of several insights, open to dialogue.

\section{CONCLUSION}

Narratives and/or short stories - process with webs and conflicts, thoughts and human acts - represent a thematic mosaic that makes possible the analysis and discussion of concepts uncritically accepted and deeply ingrained, individually and socially. The act of telling brings with itself the perception of the existence of a strong relationship between texts and contexts. It also bears the perception of possible different ways of life and the points of discussion they place are very similar to the ones we find in natural world. In this manner, while discussing projects of justice, tolerance, right to freedom, equality in treatment and acknowledgement of human dignity in narratives, we do this by analogy with the real world.

So, in our point of view, in the process that guides adult education, short narratives can accomplish an important role by leading the subject to the commitment of questioning individual and social beliefs in search of grounds to his action. As previously stated, if narratives, on one hand, symbolically involve 
Fátima Barbosa and Maria do Rosário Amaral

values, and wise effects of tradition, knowledge and experience; on the other, they unfold to new contexts and dialogues, they allow the revaluation and reinterpretation of such legacy by the light of different perspectives, because the culture of individuals submitted to education today is different.

Going beyond the limits of the texts, narratives render possible several readings essential in mutual knowledge; they can benefit the integration of adults in host societies; and finally they can promote an education towards peace, tolerance, freedom, solidarity, avoiding the domination of a unique point of view.

\section{REFERENCES}

[1] Paulo Freire, La importância de leer y el processo de liberación, Madrid: Paidós, 1984

[2] Paulo Freire, Pedagogia da Esperança - um reencontro com a pedagogia do oprimido, S. Paulo: Paz e Terra, 1997

[3] Stephen D. Brookfield, "Transformative Learning as Ideology Critique" In Learning as Transformation, S. Francisco: Jossey-Bass Publishers, pp. 125-126, 2000

[4] A. Nóvoa, "Histórias de Vida" in Educação de Adultos: Cadernos de Formação, Impresse, 1997

[5] Justino Magalhães, O Professor - Um regenerador agrilhoado, Campinas: revista Histedbr online, n-31, available at http//:www.histedbr.fae.unicamp.br, Set. de 2008

[6] José Ferreira-Alves e Óscar F. Gonçalves, 'Narrativas Psicológicas, Valores e PósRacionalismo' in A Escola Cultural e os Valores, Porto: Porto Editora, 1997

[7] M. Rosário A.S.C.M. Silva, PhD dissertation, A Racionalidade Comunicativa: contributos para a educação de Adultos, Braga: Universidade do Minho, 2008, "unpublished"

[8] Mia Couto, "O Embondeiro que Sonhava Pássaros", in Cada Homem é Uma Raça, Lisboa: Ed. Caminho, p. 62, 2005

[9] Mia Couto, "O Embondeiro que Sonhava Pássaros", in Cada Homem é Uma Raça, Lisboa: Ed. Caminho, pp.62-64, 2005

[10] Mia Couto, "O Embondeiro que Sonhava Pássaros", in Cada Homem é Uma Raça, Lisboa: Ed. Caminho, p.66, 2005

[11] Mia Couto, "A Mancha" in Cronicando, Lisboa: Ed. Caminho, p. 25, 2002

[12] Mia Couto, "A Mancha" in Cronicando, Lisboa: Ed. Caminho, p. 25, 2002

[13] Mia Couto, "A Mancha" in Cronicando, Lisboa: Ed. Caminho, p. 26, 2002

[14] Mia Couto, "A Mancha" in Cronicando, Lisboa: Ed. Caminho, p. 26, 2002

[15] Mia Couto, "A Mancha" in Cronicando, Lisboa: Ed. Caminho, p. 26, 2002

[16] Mia Couto, "A Mancha" in Cronicando, Lisboa: Ed. Caminho, p. 27, 2002

[17] Mia Couto, "A Mancha" in Cronicando, Lisboa: Ed. Caminho, p. 27, 2002

[18] Mia Couto, "Balões dos Meninos Velhos", in Cronicando, Lisboa: Ed. Caminho, p. 79, 2002

[19] Mia Couto, "Balões dos Meninos Velhos", in Cronicando, Lisboa: Ed. Caminho, p. 79, 2002

[20] Mia Couto, 'A Praça do Deuses', in Cronicando, Lisboa: Ed. Caminho, p. 183, 2002 